\title{
Rainfall variability in southeast and west-central Africa during the Little Ice Age: do documentary and proxy records agree?
}

\author{
Matthew J. Hannaford ${ }^{1}$ (D) Kristen K. Beck ${ }^{1}$ (D)
}

Received: 16 April 2021 / Accepted: 3 September 2021/ Published online: 30 September 2021

(C) The Author(s) 2021

\begin{abstract}
Understanding of long-term climatic change prior to instrumental records necessitates reconstructions from documentary and palaeoclimate archives. In southern Africa, documentaryderived chronologies of nineteenth century rainfall variability and palaeoclimate records have permitted new insights into rainfall variability over past centuries. Rarely considered, however, is the climatic information within early colonial documentary records that emerge from the late fifteenth century onwards. This paper examines evidence for (multi-)seasonal dry and wet events within these earlier written records (c. 1550-1830 CE) from southeast Africa (Mozambique) and west-central Africa (Angola) in conjunction with palaeoclimate records from multiple proxies. Specifically, it aims to understand whether these sources agree in their signals of rainfall variability over a 280-year period covering the 'main phase' Little Ice Age (LIA) in southern Africa. The two source types generally, but do not always, show agreement within the two regions. This appears to reflect both the nature of rainfall variability and the context behind documentary recording. Both source types indicate that southeast and west-central Africa were distinct regions of rainfall variability over seasonal and longer timescales during the LIA, with southeast Africa being generally drier and west-central Africa generally wetter. However, the documentary records reveal considerable variability within these mean state climatic conditions, with multi-year droughts a recurrent feature in both regions. An analysis of long-term rainfall links with the El Niño-Southern Oscillation (ENSO) in southeast Africa suggests a complex and possibly non-stationary relationship. Overall, early colonial records provide valuable information for constraining hydroclimate variability where palaeoclimate records remain sparse.
\end{abstract}

Keywords Southern Africa · Rainfall variability · Little Ice Age · Documentary reconstruction · Palaeoclimate

Matthew J. Hannaford

mhannaford@lincoln.ac.uk

1 School of Geography and Lincoln Centre for Water and Planetary Health, University of Lincoln, Brayford Pool, Lincoln LN6 7TS, UK 


\section{Introduction}

Analyses of long-term trends in rainfall variability are crucial for understanding changes in the timing, distribution, and amount of precipitation. Recent years have seen the proliferation of palaeoclimate proxy records in southern Africa and the African continent (Nash et al. 2016a). Datasets covering the late Holocene have been developed from speleothems (Holmgren et al. 1999, 2003; Sletten et al. 2013; Scroxton et al. 2017; Voarintsoa et al. 2017; Braun et al. 2019), mammalian middens (Chase et al. 2009; Scott 1996), tree rings (Woodborne et al. 2016), pollen (Ekblom et al. 2012), and lake records (Stager et al. 2013), all of which can be representative of precipitation variability. However, annually resolved palaeoclimate records remain sparse in comparison to other regions and continents, including other southern hemisphere landmasses such as South America and Australasia (Neukom and Gergis 2012). With widespread instrumental recording not beginning until the late nineteenth century, this presents challenges in understanding inter-annual to decadal climate variability over historical timescales.

In the absence of high numbers of annually resolved rainfall reconstructions, documentarybased reconstructions have taken on particular importance in extending existing records of seasonal rainfall variability and extreme events (Allan et al. 2016; Nash et al. 2016b; Neukom et al. 2013; Nash and Hannaford 2020). Written records produced by missionaries, colonial governments, and various diarists have provided sufficient qualitative material for systematic reconstructions of 'wetness' across large parts of modern-day South Africa from the 1820s (Vogel 1989; Nash and Endfield 2002; Kelso and Vogel 2007; Nash et al. 2016b), Namibia from the 1840s (Grab and Zumthurm 2018), and Malawi from the 1860s (Nash et al. 2018). Wind data recorded within ships' logbooks have also been used to reconstruct precipitation in South Africa from the 1790s onwards (Hannaford et al. 2015).

At present, however, analysis of documentary sources for information on past climate variability in the region has been largely confined to the nineteenth century. This is not wholly surprising: the volume of written documentation produced in the region rose rapidly with each passing decade of that century, geographical coverage expanded, and increases in missionary correspondence - one of the richest sources for documentary-based climate reconstruction (Nash et al. 2019) - played a key role in both of these trends. Yet first-hand observers, including missionaries, had been writing about the climate of the region for large parts of the preceding three centuries, especially southeast and west-central Africa, which fell under Portuguese colonisation (Beach 1987; Jones 1987). Importantly, these narrative records extend back into the coolest parts of the Little Ice Age (LIA) in southern Africa (c. 1690 to 1740; Sundqvist et al. 2013). ${ }^{1}$ While LIA cooling appears to be a consistent feature in southern African palaeoclimate records and geographical variability in LIA hydroclimates has been observed between southeast Africa and west-central Africa (Nash et al. 2016a), few studies have examined the occurrence, frequency, or duration of (multi-)seasonal rainfall variability and extremes during this period, or their relationship to multi-decadal climatic change captured by most regional palaeoclimate records. Additionally, relationships with the climate drivers that modulated rainfall variability during the LIA, such as the El Niño-Southern Oscillation (ENSO) and the Intertropical Convergence Zone (ITCZ), require further investigation due to their complex and at times covarying nature.

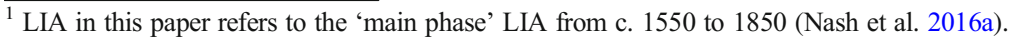


Early colonial documentary sources are not without their problems. Coverage varies between decades and across space, as did the interests of the observers. Equally, the annual volume of material produced was generally far less than that of the nineteenth-century material used for systematic reconstruction. These limitations notwithstanding, the deeper historical record provides a valuable source of evidence for exploration of climate variability in the centuries before instrumental records (Nicholson 1979, 2018; Hannaford 2020). Many observers resided in the region for years or even decades, and the topics covered within their written accounts were relatively wide - even if dominated by topics considered important for economic, political, and religious matters (Beach 1987). Weather and climate, as it happened, were important for all three. Flooded rivers or storms could impede trade over land or sea, while droughts could destroy the production of foodstuffs that helped sustain the colonial foothold in the region (Hannaford 2018b). Climate was believed to be crucial in the spread of infectious diseases or the more general health of different parts of a region. Missionaries also recorded aspects of indigenous African religion that they sought to supplant, such as mukwerera (asking for rain) (Chirikure et al. 2017), and its perceived relationship with drought. All of these factors meant that rainfall variability, together with more generic climatic and landscape observations, was recorded in various source types that characterise the early colonial documentary record, but also that 'silences' - periods where references to climatic conditions are absent despite a continuity of written recording - can provide further clues into long-term rainfall variability.

In view of the advantages and limitations of the sources of past climatic information presented above, this paper cross-compares documentary and proxy records in order to investigate rainfall variability in the centuries prior to the start of the instrumental meteorological record. In particular, it revisits, revises, and adds to existing documentary-based rainfall chronologies from the mid-sixteenth to early nineteenth centuries for Mozambique (Liesegang 1993; Ekblom and Stabell 2008; Hannaford 2018b; Pikirayi 2003) and Angola (Miller 1982). It then compares these to evidence from multiple proxy-derived hydroclimate reconstructions from these regions that span the same time period at variable resolutions (centennial-annual). The aim of this work is therefore threefold: first, to examine and explain the comparability between early colonial documentary records and palaeoclimate records; second, to better understand hydroclimate variability within and between two regions of southern Africa over the LIA; and third, to explore relationships with drivers of hydroclimate variability in these regions, particularly long-term rainfall links with the ENSO.

\section{Climatic context}

The focus regions of the study are the areas that form modern-day Mozambique and Angola (Fig. 1), which sit within the tropical and subtropical southern latitudes. These regions have been selected because of the availability of documentary information on climate variability dating back to the mid-sixteenthcentury - a relatively early date for Africa south of the Sahara and outside of the West African coast and the Sahel (Nicholson 2018). The Electronic Supplementary Material (ESM) provides additional background to the historical context of the two regions across the study period (Section S1), with particular reference to how this affected the geographical and chronological coverage of documentary evidence.

Mozambique and Angola lie within the Summer Rainfall Zone (SRZ) of sub-equatorial Africa, where most precipitation falls between November and April. For the purposes of this 

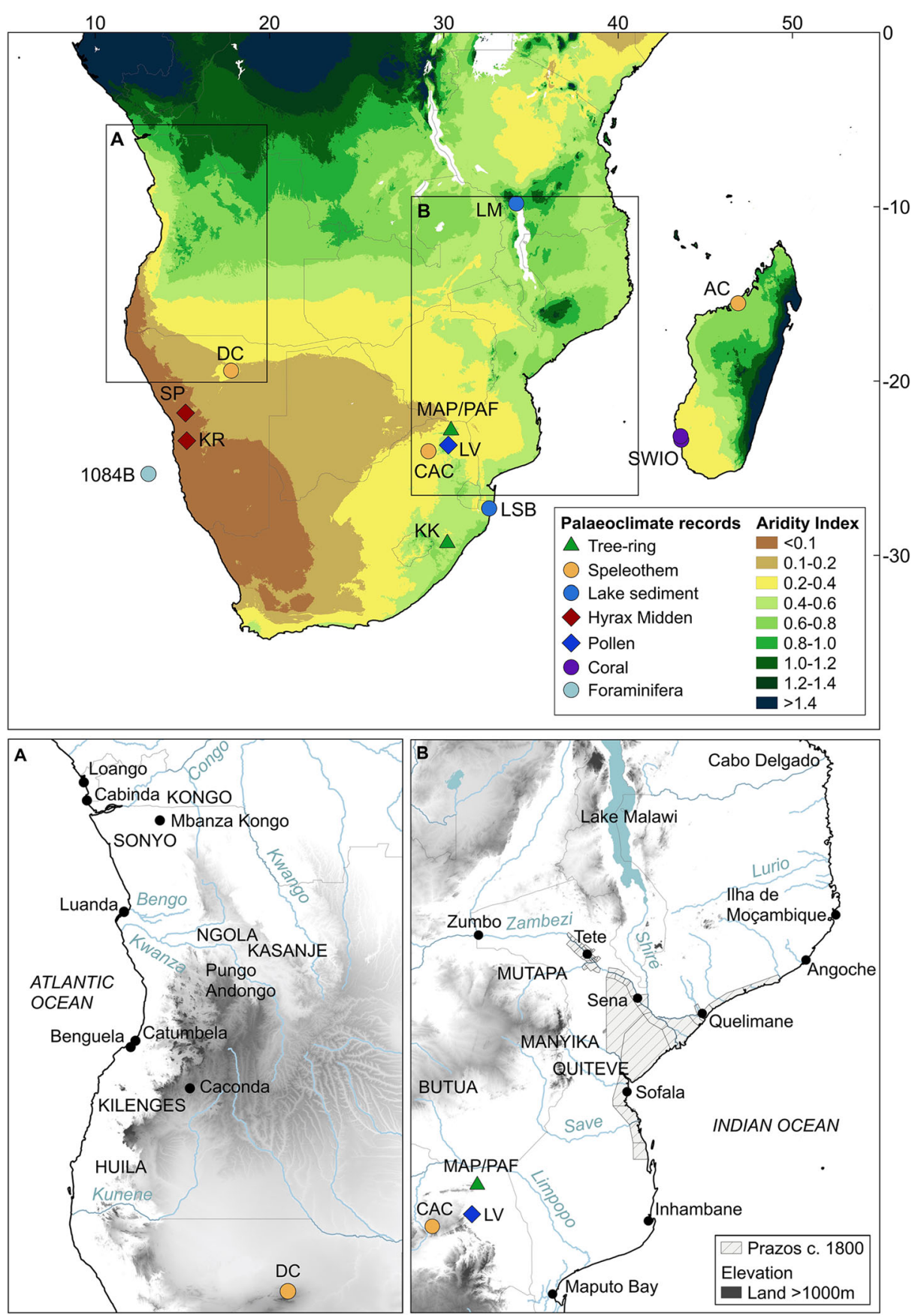

Fig. 1 Aridity index map (Trabucco and Zomer 2018) of sub-equatorial Africa with sites mentioned in the text. Panel A shows Angola (west-central Africa) and panel B Mozambique (southeast Africa) and adjacent areas. Palaeoclimate record sites displayed by coloured symbols are detailed in Table 1. Prazos represent area of Portuguese-held estates at c. $1800 \mathrm{CE}$ 
paper, these areas can be separated into two climatic regions: the Summer Rainfall Zone East (SRZE) and Summer Rainfall Zone West (SRZW). A principal component analysis of interannual rainfall variability during the nineteenth and twentieth centuries found variability within these larger regions is generally in-phase(Nicholson 2014). However, important exceptions in some principal components include an opposition between coastal Angola and northern Namibia in the SRZW, and opposing rainfall anomalies north and south of around $25^{\circ} \mathrm{S}$ in the SRZE. Additionally, rainfall variability displayed an east-west opposition between the SRZE and SRZW. This opposition has also been observed over multi-decadal to centennial timescales across the LIA, with LIA cooling associated with drying in the SRZE and wetting in the SRZW (Nash et al. 2016a). These patterns are likely reflective of the mixture of related atmosphere-ocean drivers of rainfall variability described below.

Rainfall in the SRZE is derived from tropical-temperate troughs (Williams et al. 2007). These form as the ITCZ and Congo Air Boundary (CAB) — which mark the boundary of zonal wind convergence between Atlantic and Indian Ocean air streams - move southward during the austral summer. Warm sea surface temperatures (SSTs) in the southwest Indian Ocean are associated with increased rainfall in the SRZE on seasonal to interdecadal scales (Neukom et al. 2013), while the positive phase of the Indian Ocean Dipole (IOD) is linked to dry conditions in southeast Africa (Abram et al. 2020). Moisture conditions are also influenced by ENSO, which influences the mean position of tropical-temperate troughs (Williams et al. 2007). During the El Niño phase, the SRZE experiences drier summers, and the La Niña phase is associated with the opposing response. Wetter conditions over the SRZE are also associated with positive phases of the Southern Annular Mode (SAM), whereas negative phases bring drier conditions through a northward extension of the westerlies (Gillett et al. 2006). Rainfall is generally higher along the coast and decreases further inland due to orographic effects. The central Mozambican coastal settlements of Beira, near the historical settlement of Sofala, and Quelimane, receive a mean annual precipitation of $\sim 1400-1500 \mathrm{~mm}^{2}$ This figure drops to $\sim 900 \mathrm{~mm}$ around Mozambique Island (Ilha de Moçambique) and $\sim 800 \mathrm{~mm}$ at Maputo. Moving up the Zambezi, Chemba, proximate to the historical settlement of Sena, receives $\sim 700 \mathrm{~mm}$ rainfall per annum; this falls to $\sim 600 \mathrm{~mm}$ at Tete $400 \mathrm{~km}$ upstream.

SRZW rainfall is similarly linked to the annual movement of the ITCZ and the CAB (Nicholson 2000). Rainfall amount is also strongly associated with SSTs and upwelling in the southeast Atlantic. Southwesterly flows of dry air are linked to the cold Benguela current and restrict the influx of easterly moisture streams from the Indian Ocean (Jury and Engert 1999), which results in greater aridity along the coast (Fig. 1). However, above normal SSTs linked to a more southerly position of the Angola-Benguelafront-where the warm Angola ocean current meets the Benguela current - deliver late summer rainfall along the coast and inland (Rouault et al. 2003). Moisture conditions are also influenced by ENSO. During El Niño years, circulation changes can lead to a weakening of the Angola Low (Crétat et al. 2019), which may reduce rainfall over northern Namibia and southeast Angola. However, less consistent anomalies are observed in the Angolan coastal zone (Hoell et al. 2015). La Niña years tend to be associated with drier conditions in the coastal zone and more varied conditions inland and in northern Namibia (Hoell et al. 2015). The coastal settlements of Benguela and Luanda, from

\footnotetext{
${ }^{2}$ All figures are from Nicholson's Africa monthly precipitation dataset, 1901-1984. Mozambique reference periods are Beira 1913-1984, Quelimane 1908-1984, Mossuril (near Mozambique Island) 1913-1973, Maputo 1892-1984, Chemba 1931-1981, and Tete 1908-1984. Angola reference periods are Benguela 1944-1973, Caconda 1949-1973, Luanda 1901-1984, and Mbanza Kongo 1917-1973 (gaps in 1930s/1940s) (Meteorology Department/Florida State University 1980).
} 
where most of the Angolan written records derive, receive a mean annual precipitation of $\sim 250 \mathrm{~mm}$ and $\sim 360 \mathrm{~mm}$, respectively. These lowland coastal regions experience the highest levels of inter-annual rainfall variability in the region (Dias 1981). Mean annual precipitation rises to $\sim 1250 \mathrm{~mm} 220 \mathrm{~km}$ inland at Caconda in the highlands and a similar total $175 \mathrm{~km}$ inland at Mbanza Kongo.

\section{Materials and methods}

\subsection{Documentary rainfall chronologies}

This paper uses two documentary chronologies of seasonal rainfall conditions for July-June 'rain-years' over the period 1550-1830. The Mozambique chronology expands substantially on previous identifications of droughts by Liesegang (1993), Nicholson (1996), Pikirayi (2003), and Ekblom and Stabell (2008) through consultation of published and unpublished European, primarily Portuguese, documentary materials (as outlined in Hannaford 2018a) and secondary literature on the history of the region. The chronology for Angola was adapted from the compilation of climatic extremes and epidemics published by Miller (1982), which was based on consultation of Portuguese archival records at the Arquivo Histórico Ultramarino and published secondary literature.

The methods underpinning the construction of the two documentary chronologies follow an established tradition of historical climatology research in Africa (Nicholson 2018, 1979; Nash et al. 2019; see ESM S2 for further background on climatic information within early colonial documents and its resolution). All climate-related information was recorded verbatim and assigned to July-June 'rain-years' unless otherwise stated. Where documents were consulted as English translations, in most cases, the documents were consulted in their original language to ensure accuracy. In years where rainfall classifications were possible, conditions were simply classified as wet or dry, with no attempt to quantitatively distinguish the severity of wet and dry conditions (as in Miller 1982; Nash et al. 2016b). While qualitative distinctions were possible for some years with a high volume of observations, the more limited information available in other years would enforce too high a degree of subjectivity on the classifications to render them comparable. The occurrence of locust swarms or plagues was also categorised as outbreaks are known to be responsive to seasonal climatic conditions (Steedman 1990; Bahana and Ngazero 1999). Specifically, gregarious behaviour of the red locust (Nomadacris septemfasciata) increases as rainfall deficits reduce available habitat and increase locust density. This can cause migratory swarms to become displaced from outbreak areas in central Mozambique and southern Malawi, including westwards towards Angola (Steedman 1990).

Confidence intervals were assigned to seasonal classifications in both chronologies to avoid false equivalence of classifications based upon varying quality and quantity of evidence (following Kelso and Vogel 2007). A 3-point scale was used. '1' equals low confidence, where reports may derive from single second-hand observer, contain imprecision over the timeframe, or consist of an indirect reference to possible climate impacts such as a shortage of food or water. '2' represents medium confidence, where reports may still derive from a single observer but are reported at first-hand, are more richly descriptive, or include direct references to climatic phenomena. ' 3 ' equals high confidence, which typically includes multiple firsthand descriptions of the same phenomenon with specific dates and locations. 
Finally, the range of evidence used as indicators of drought in the original Angolan chronology published by Miller (1982) was narrowed to ensure greater comparability with the Mozambique chronology. For example, Miller's (1982) dataset includes multiple instances where warfare was taken as indirect evidence for drought due to the common coincidence between the two. Here, however, unless there is an explicit link between drought and specific conflicts, these indirect classifications were removed due to the complexities associated with this assumption. Specifically, while drought could stimulate conflict via a decline in available foodstuffs, conflict itself could also cause food shortages which precipitate further conflict, causing the chain of causation to become reversed (van Bavel et al. 2019). This resulted in the removal of three possible hydroclimate-related entries from the original Angola chronology. ${ }^{3}$

\subsection{Palaeoclimate records}

In order to enable comparison with documentary records, palaeoclimate records were selected on the basis that they (i) represent past rainfall or moisture, (ii) cover the time period of interest (1550-1830 CE), and (iii) fall within the SRZE or SRZW. For speleothem isotope records, reconstructions for both $\delta^{13} \mathrm{C}$ and $\delta^{18} \mathrm{O}$ were included due the multi-factorial influences that affect these proxies (Lachniet 2009; Fohlmeister et al. 2020). While annual data are preferable and have permitted high-resolution comparison between documentary and proxy records in other regions (Kiss 2017; White 2019), resolutions up to centennial timeframes were used in some cases, particularly for areas with very few reconstructions (i.e. SRZW) (Table 1).

Based on our criteria, palaeoclimate reconstructions from annual to centennial resolution were selected from 10 sites (Table 1): seven from the SRZE and three from SRZW. Proxy types include isotopes, diatoms, tree ring widths, biogenic silica, and pollen. SRZE records are primarily derived from northeast South Africa at around $23-24^{\circ} \mathrm{S}$, including the two speleothem isotope records from CAC and the annually resolved MAP/PAF carbon isotope record derived from baobab trees, with further records from southeast South Africa at around 27-29 S and Lake Malawi (Fig. 1). SRZW records are scarce, with no records at centennial resolution or above for modern-day Angola itself. Records are therefore drawn from northeastern or central Namibia, the highest resolution of which is the DC1 record from the speleothem isotope record at $19.4^{\circ} \mathrm{S}$ (Voarintsoa et al. 2017). Lower resolution pollen and isotopic proxies from hyrax middens supplement these records (Scott 1996; Chase et al. 2009). In addition, hydroclimate reconstructions from Anjohibe cave in northwestern Madagascar (Scroxton et al. 2017) and eastern African lakes (Tierney et al. 2013), as well as reconstructions of southwest Indian Ocean SSTs derived from coral records (Zinke et al. 2014) and southeast Atlantic upwelling (Farmer et al. 2005), were examined for evidence of rainfall variability in neighbouring regions and drivers of rainfall.

Palaeoclimate reconstructions were trimmed to show only the period between 1500 and 1900 CE. The data were first plotted by region (Section 4.2). To enable comparison with documentary chronologies, hydroclimate residuals ( $z$-scores) were calculated using the mean of the records over the timeframe 1500-1900(Section 5.1). Given the limited quantity of annually resolved proxy data and the possibility of temporal errors in the age models of these series, the comparison examined the timing, frequency, and duration of dry and wet rain-years in the documentary chronologies, as well as their absences, in relation to rainfall variability at

\footnotetext{
${ }^{3}$ The years excluded are 1568 (famine likely a result of war), 1572 (war tentatively linked to drought), and 1601 (felling of palm groves for edible pulp, but ample foodstuffs otherwise reported).
} 


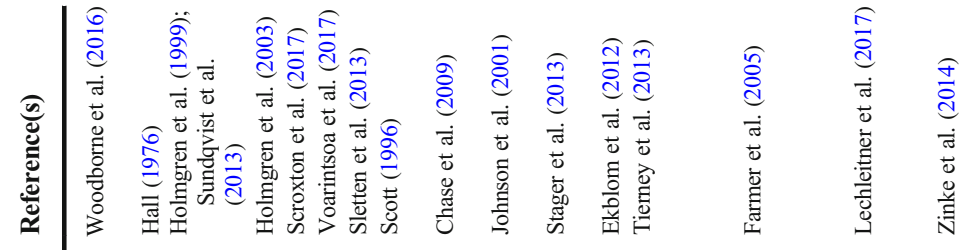

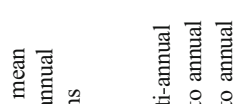

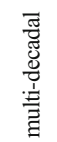

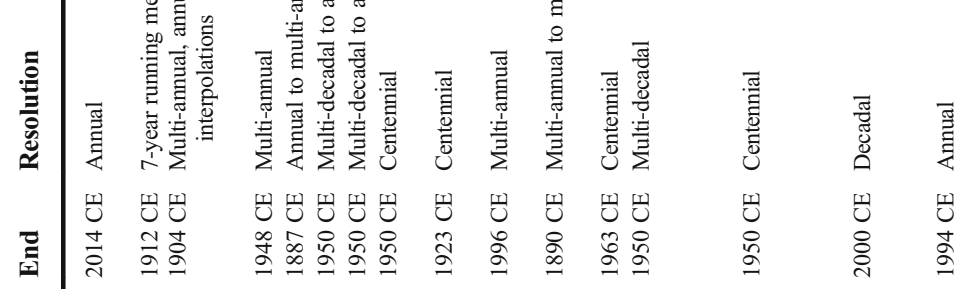

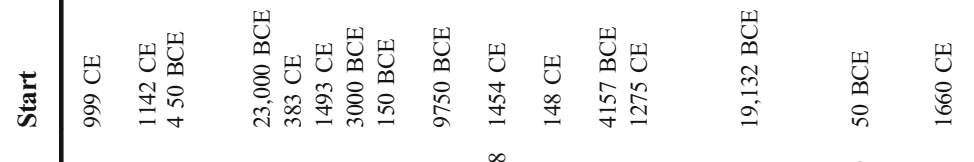

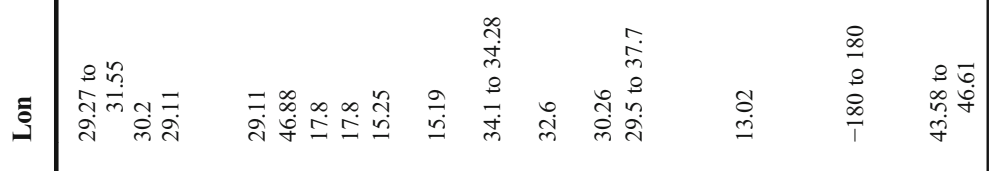

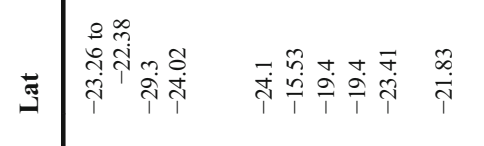

$$
\bar{\infty}
$$

$\infty$

임 
longer (decadal-centennial) timescales within palaeoclimate records covering the LIA. Much of the focus of the comparison was given to the higher resolution palaeoclimate records, which capture rainfall variability across timescales (annual to decadal) more analogous to the documentary records. However, the lower resolution records provided important context on mean state variability. Observed patterns were also compared with reconstructions of possible drivers of rainfall variability, including SSTs from the Agulhas Current region (Zinke et al. 2014), global ITCZ sensitive sites (Lechleitner et al. 2017), and ENSO (Gergis and Fowler 2009)(Section 5.2).

\section{Results}

\subsection{Documentary chronologies}

Figure 2 shows a comparative view on the occurrence of drier and wetter events in Mozambique and Angola, coloured by the confidence interval assigned to each classification (full details and references are presented in Table S1 for Mozambique and Table S2 for Angola). In total, 42 hydroclimate-related events, spanning 68 rain-years, are observed for Mozambique, in contrast to 65 hydroclimate-related events, spanning 87 rain-years, for Angola. High or medium confidence was ascribed to most seasonal classifications in both regions - 51 in Mozambique and 69 in Angola.

In both regions of interest, reports of drier rain-years $(n=51,18 \%$ of total years in Mozambique; $n=69,25 \%$ in Angola) exceed wetter rain-years ( $n=17,6 \%$ in Mozambique; $n=18,6 \%$ in Angola). This pattern is present in each of the centuries (Fig. S1), including when classifications with low confidence are excluded. At this point, it should be noted that over-representation of drier seasons is common in documentary reconstructions in dryland areas (Nash et al. 2016b), although the opposite pattern has been observed in central Namibia (Grab and Zumthurm 2018). The discrepancy in the number of droughts between the two areas may be expected due to the overall quantity of written documentation produced for the two areas in the period of interest (see Section S1). However, this may also relate to the drier baseline climatic conditions of coastal Angola. The latter explanation is substantiated by the greater comparability in the number of wet events reported between the two regions.

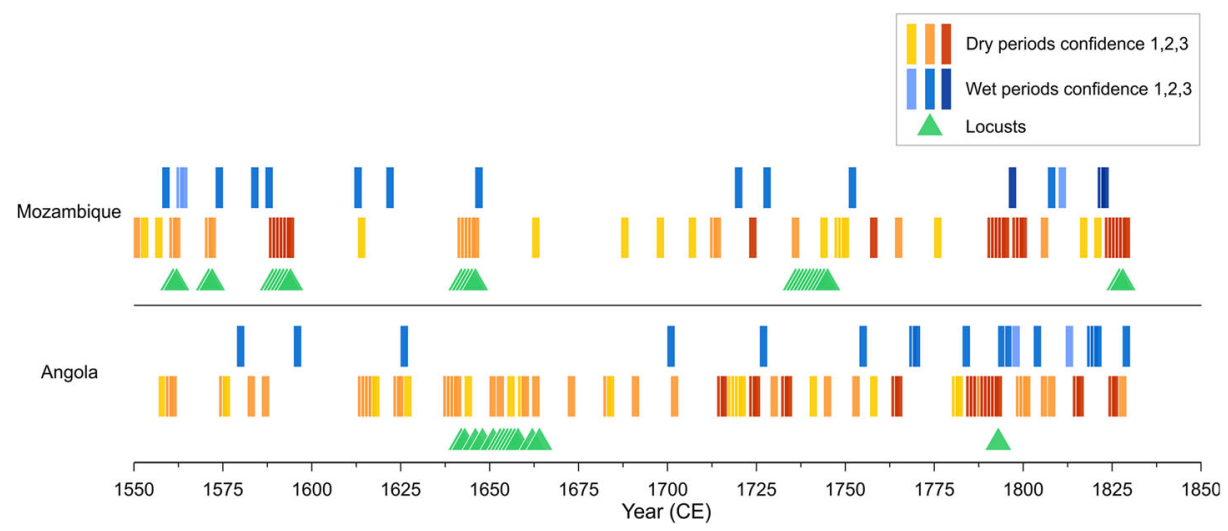

Fig. 2 Documentary-derived seasonal hydroclimate-related events in Mozambique and Angola, 1550-1830 
In Mozambique, the early nineteenth century had the highest proportional total of rain-years with classifications as either dry or wet, with $33 \%$ of its 30 years classified as dry. The late sixteenth century had the second highest proportional total of dry years, followed by the eighteenth century, while the seventeenth century had the lowest proportional total. In Angola, the early nineteenth century and the eighteenth century both had the highest proportional totals of dry years, each with $30 \%$. A different trend is observed for wetter conditions, where in Angola, the late sixteenth century witnessed more reports of wetter years than the seventeenth century. The same broad pattern is observed for Mozambique, where the proportion of wetter years was at its lowest in the seventeenth and eighteenth centuries.

Geographically, references to hydroclimate-related events come from a spread of modernday Mozambique and neighbouring areas of the SRZE, with no dominant area (Table S1). Several multi-year droughts also affected large parts of the region in tandem (Section 4.1.1). Reports of hydroclimate-related events in Angola centre around Luanda, Benguela, and adjacent parts of the coastal zone (Table S2). Reports of drought come from a wider range of locations during the sixteenth, seventeenth, and early nineteenth centuries, while the eighteenth-century reports mostly derive from Luanda and Benguela. Few references to drought relate to the interior highlands beyond the middle Kwanza or the Kingdom of Kongo. Coherence in the timing of drought between Mozambique and Angola is limited, with only 15 seasons simultaneously classified as dry in both regions, eight of which fall within the multiyear drought periods from the 1790 s onwards.

The potential extent to which the patterns described above derive from the nature of climatic conditions versus the production of documentary material and observer interest will be discussed in Section 5.1.

\subsubsection{Evidence for drier periods}

In Mozambique, the 51 rain-years classified as dry (37 > low confidence) include nine multiyear dry periods $(1561-1563,1571-1573,1589-1595,1642-1647,1713-1715,1748-1751$, 1791-1796, 1798-1801, 1824-1830, eight > low confidence). In 1561-1563, drought was reported to have affected the coast and inland, with resort to famine foods such as caterpillars around Inhambane. Drought was also accompanied by an outbreak of locusts. Drought of similar duration was said to have affected the Zambezi from Sena to Tete, Manyika, and Mozambique Island in 1571-1573. The most detailed descriptions of this event come from Francisco de Monclaro, whose descriptions of dry conditions may partly stem from his encounter with an environment unfamiliar to a colonial observer. However, corroboration comes from Manyika, while food was scarce and 'very dear' at Mozambique Island. A third, more extended period of drought struck the SRZE from 1589 to 1995. Here, João dos Santos described the severe effects of the 'great sterility and famine' that reigned along the Zambezi and Mozambique coast, which combined with a plague of locusts and a severe outbreak of smallpox. The shipwreck account from the Santo Alberto, wrecked off the South African coast in 1593, corroborates the wide extent of this drought in its descriptions of scarce provisions from present-day KwaZulu-Natal to Maputo Bay caused by want of rain.

The only multi-year drought recorded during the seventeenth century was that of $1642-$ 1647, when a survivor of the shipwrecked Nossa Senhora da Atalaya reported that it had not rained for 5 years throughout the whole region, causing great famine and a plague of locusts. The latter half of the century seems to have been more remarkable for its epidemics than 
climatic extremes (Axelson 1960), with only three other possible dry rain-years found within the documentary record, all of which were assigned low confidence.

Reports making explicit reference to drought and its severity increase during the eighteenth century. Drought in 1713-1715 was described as 'remarkable', and the resultant famine, together with a smallpox epidemic, resulted in mass mortality. Later in the century, Lacerda wrote of the 'great droughts' that struck Tete and the wider Zambezi area from 1792 to 1796. This forced a reliance on banana tree roots and other famine foods, eventually resulting in a large death toll amongst people and livestock alike. Drought returned across the SRZE in 1798-1801. Grain prices around Tete reached high levels in 1798, while in 1801, Diniz described a drought that had been raging for several years in Butua. In southeast South Africa, oral traditions refer to this period as the mahlatule famine (Hannaford 2020). In 1824-1830, the most protracted drought reported since 1589-1595 hit the SRZE, which Newitt (1988) refers to as the 'Great Mozambique drought'. The highest concentration of reports comes from the lower Zambezi, where drought, relieved only by short rains in 1827, but thereafter accompanied by locusts, helped trigger mass mortality and the breakdown of social order. Famine was also reported in southeast South Africa at this time (Hannaford and Nash 2016).

In Angola, the 69 rain-years classified as dry (53 > low confidence) include 13 multi-year dry periods (1560-1562, 1614-1618, 1624-1626, 1638-1642, 1715-1717, 1718-1722, 1724 1726, 1733-1735, 1764-1766, 1785-1794, 1799-1802, 1815-1817, and 1825-1827, 12 > low confidence). Evidence for multi-seasonal droughts during the sixteenth century is limited to multiple reports of food shortages, social tensions with rainmakers, and slaughter of cattle in the Ngola capital inland of Luanda in 1560-1562. Three multi-seasonal droughts affected Luanda and the lower Kwanza valley during the seventeenth century. Between 1614 and 1618 , it was reported not to have rained at Luanda. A decade later, in 1624-1626, there was a backto-back failure of the rains at Luanda, with concurrent reports of food shortages in the Kwanza valley. Drought returned to the lower Kwanza area in 1639-1642, corresponding with shortages of food at Benguela. The mid-century period also witnessed very high numbers of reported locust plagues. Dry rain-years were reported in the Kongo and Sonyo areas on a number of occasions during the remainder of the seventeenth century, with a concentration of poorly dated multi-year droughts at Benguela between 1656 and 1666 (Miller 1982). There were relatively few reports of droughts around Luanda during the later seventeenth century.

An increase in reports of multi-seasonal dry periods was observed during the eighteenth century, especially in the coastal area. In 1715-1717, lack of rain prompted food shortages, substantial rises in the price of grain and the establishment of a price ceiling at Luanda, and famine mortality inland. In March 1726, it was reported that no rain had fell at Luanda and in the adjacent interior for at least 2 years, leading to unprecedently high grain prices. Back-toback failures of the rains at Luanda returned once again in 1733-1735, leading to a 'great famine' throughout the realm, including the interior by 1736 (Miller 1982). A similar situation prevailed in these areas in 1764-1766. Severe drought struck Luanda for 3 years in 1785-1788, with a complete failure of the rains causing food shortages and requests for imports. Drought continued in 1788-1789, and the rainy seasons of 1789-1794 brought even less rainfall, resulting in the 'worst famine ever recorded at Luanda', with food shortages also extending inland (Miller 1982). Famine mortality reached Benguela by 1793, where after a failure of the 1793-1794 rainy season, it was reported that animals began to attack people. Protracted aridity and food shortages returned to Luanda in 1799, with grain prices remaining high until 1802.

Two further periods of multi-seasonal drought were reported during the early nineteenth century. In 1815-1817, it was noted that no rain fell at Luanda for 2 years, while drought was 
also reported from the central highlands in 1817. A later drought in 1825-1827 was more spatially extensive, with its impacts reported at Catumbela in 1825 and further reports in the central highlands and at Luanda over the following 2 years, with high mortality amongst people and livestock at the latter.

\subsubsection{Evidence for wetter periods}

In contrast to drought phases, almost all of the 17 wet rain-years reported in Mozambique (14 $>$ low confidence) lasted a single season. During the late sixteenth century, wet rain-years and floods were reported to follow or precede droughts during the early $1560 \mathrm{~s}$, the early $1570 \mathrm{~s}$, and the late 1580s. In most cases, wet conditions seem to have been a result of above-average seasonal precipitation rather than short-duration storms. Evidence of wetter seasons during the seventeenth century comes from shipwreck accounts, with numerous references to heavy rains and the ripening of crops in 1622-1623 and in late 1647. Several accounts written in this period also make generic references to the fertility and well-watered nature of the Zambezi. However, these do not allow classification of specific rain-years. The Dutch dagregister kept at Delagoa Bay (Maputo) in 1728-1829 describes relatively wet conditions for most of that rain-year, as did Pereira's account of his journey from Quelimane to Angoche in 1752-1753. Lacerda also reported that the season of 1797-1798 had been 'very rainy' in the Zambezi area. Further references to wet conditions during the early nineteenth century accounts include direct reports of wet conditions throughout 1822-1823, with more indirect references to full water tanks and 'sickly' conditions at Mozambique Island in 1808-1809 and 1811-1812.

Similar to Mozambique, most of the 18 wet rain-years reported in Angola (17 > low confidence) lasted for a single season. During the sixteenth century, reports of heavy rains came from the Kwanza valley (1580) and the lower Bengo (1596), the latter of which was linked with the cause of disease amongst Portuguese troops. Heavy rains and disease also blighted a Portuguese expedition to the Congo River in 1627. References to wet rain-years increase during the eighteenth century. In 1701, unusually intense rainfall was reported to have ruined streets in Luanda. In 1728, wetter conditions helped grain prices at Luanda return to normal levels following periods of drought, and deluges in that year brought down houses and washed away paths in Luanda. The rain-years of 1769-1771 were likely relatively wet, with abundant harvests recorded at Luanda. Ample rains were also reported at Luanda in 1784 $1785,1795-1797$, and 1798-1799, with those in 1796-1797 causing severe damage to houses and linked with disease at Benguela. Further references to wet rain-years occur during the nineteenth century. Unusually early and excess rains hit Luanda in 1805 and floods were reported along the Catumbela River near Benguela during the early part of the 1813-1814rainyear(Miller 1982). Heavy rains at Luanda during the 1818-1819rain-year caused damage to infrastructure, with rainfall plentiful at Luanda and Benguela in 1820-1822. Further torrential rains were reported at Benguela in 1829, causing buildings to collapse.

\subsection{Palaeoclimate reconstructions}

Palaeoclimate reconstructions for the SRZE, SRZW, neighbouring regions, and proximate hydroclimate drivers are shown in Fig. 3, with patterns between the two regions broadly in antiphase. SRZE sites LSB, LV, KK, CAC T7/T8, and MAP/PAF show some consistency from the sixteenth to nineteenth centuries, but display more complex intra-regional variability on decadal-multi-decadal timescales than within the SRZW. Most sites show increased 

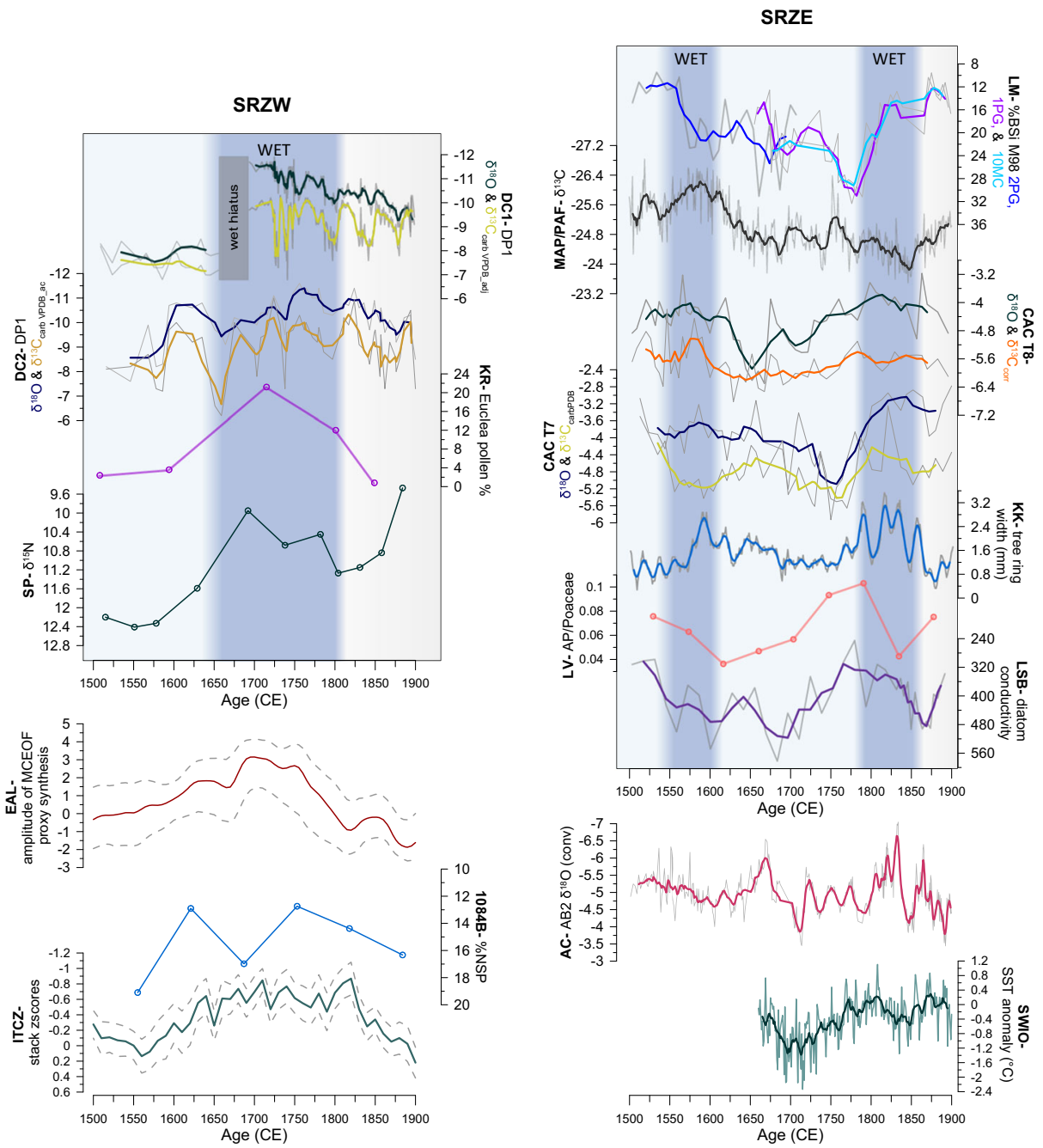

Fig. 3 Palaeoclimate stack of the selected reconstructions from SRZW, SRZE, neighbouring regions, and hydroclimate drivers (see Table 1 for references)

wetness from c. 1550 to 1600 , apart from sites LV and LSB, followed by drying and higher multi-decadal variability from c. 1600 to 1750 . Wetter conditions are observed at KK and CAC T7 at c. 1650 to 1675 , as well as in the ITCZ-sensitive AC record from northwestern Madagascar (Fig. 3; Scroxton et al. 2017). Generally wetter conditions prevail across the SRZE from c. 1780 to 1850 , punctuated by drought at c. 1800 at most sites, especially LM (Fig. 3). Offsets in the timing of transitions between palaeoclimate records could be due to the type of natural archive and the dating methods (i.e. lake records vs. tree rings). However, they may be real artefacts of the climate transitions and regional to local climate variability. Moisture patterns in this region are consistent with reconstructed southwest Indian Ocean (SWIO) SSTs (Fig. 3), with cooler SST anomalies at c. 1680-1750 and a shift towards warmer anomalies thereafter, corresponding to hydroclimate conditions in the majority of the SRZE records. 
Records from the SRZW display consistent drier conditions from c. 1500 to 1600 , followed by increased wetness from c. 1650 to 1800 . The more highly resolved DC records nevertheless indicate relatively high variability in $\delta^{13} \mathrm{C}$, which although subject to multi-factorial influences has been interpreted as evidence for moisture availability (Voarintsoa et al. 2017). Higher $\delta^{13} \mathrm{C}$ values (i.e. drier conditions) are observed around c. 1650, c. 1725, and c. 1780-1800(Fig. 3), whereas lower $\delta^{13} \mathrm{C}$ values (i.e. wetter conditions) are observed at c. $1575-1600$ (DC2, Fig. 3) and c. 1675-1700 in both DC records. There is a general decline in wetness from c. 1800 to 1900 at DC and KR; however, at SP, there is a decrease in wetness at c. 1775 followed by an increase at c. 1850. Slower centennial-scale transitions in SRZW hydroclimate follow shifts in the mean latitudinal position of the ITCZ (Fig. 3). Specifically, when the ITCZ is in a more southerly position, as from c. 1650 to 1850 , greater moisture is observed in the SRZW. SRZW records also show correspondence with upwelling in the southeast Atlantic Ocean (Farmer et al. 2005). Lower upwelling intensity is shown at c. 1625 , c. 1750 , and c. 1800 , which corresponds to increasing moisture over land, whereas increased upwelling at c. 1550 is associated with drier conditions (Fig. 3). LIA moisture conditions in the SRZW also show strong coherence with lake records from easternmost Africa (Fig. 3; Tierney et al. 2013).

\section{Discussion}

\subsection{Do documentary and proxy records agree?}

The two documentary chronologies were compared to the hydroclimate reconstruction $z$-scores from the SRZE and SRZW (Fig. 4). General, but inconsistent, agreement is found between the two source types within both regions, with strong correspondence in some parts of the LIA and weaker coherence in others. These patterns can be explained by both the rainfall variability and contextual factors behind the nature of documentary recording, as discussed below.

In Mozambique and the SRZE, palaeoclimate records show a wet-dry-wet pattern across the LIA, with considerable temporal variability within, and spatial variability between, the records at multi-decadal timescales. Drier periods show some consistency with the frequency of (multi-)seasonal droughts reported by historical observers. Both sources show a predominance of dry conditions from c. 1600 to 1750 (Fig. 4). Correspondence is evident in the midseventeenth century, when protracted drought and locust plagues parallel drier events at CAC, MAP/PAF and in the lower-resolution LV record. Similarly, reports of drought and locust plagues increase from c. 1700 to 1750 , when almost all palaeoclimate records show very dry conditions, consistent with the peak of LIA cooling in southern Africa (Sundqvist et al. 2013). This period also saw the lowest SSTs in the SWIO coral record, with the lows at c. 1713-1715 corresponding with severe drought, famine, and a smallpox epidemic inland. The protracted droughts of the 1790s appear to be captured at LM in particular, as well as at LSB and MAP/ PAF. Severe and protracted drought during the mid/late 1820s also corresponds to a decline in southwest Indian Ocean SSTs and drier conditions at MAP/PAF, LV, and KK (Fig. 4).

Less consistent patterns are found during the early and late seventeenth century, when the number of documentary references to drought reduces to a low, but palaeoclimate records show generally drier or mixed signals. There is no immediately obvious historical reason for the reduction in written reference to drought, especially as this period marked the highpoint of Portuguese expansion in the region (Section S1). Rather than the quantity of available evidence, other explanations may be that private traders, who dominated the southeast African 

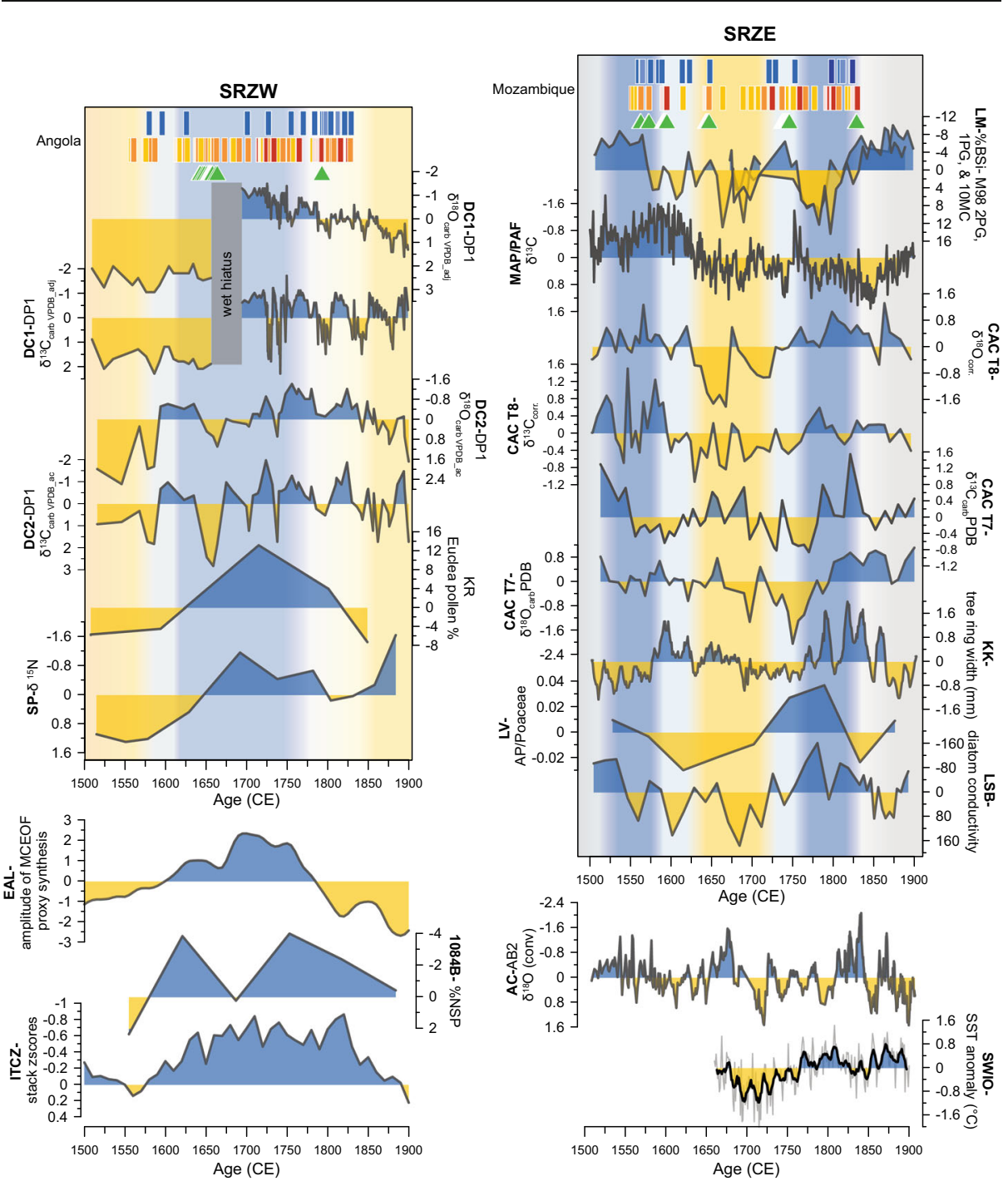

Fig. 4 Palaeoclimate reconstruction z-scores from SRZW, SRZE, neighbouring regions, and hydroclimate drivers (see Table 1 for references). Blue shading indicates wetter conditions than the mean over 1500-1900 $\mathrm{CE}$, and yellow represents dry conditions. In the documentary chronologies, darker hues indicate high confidence and lighter hues indicate low confidence (scales 1-3)

interior for parts of the seventeenth century (e.g. the 1650 s to $1670 \mathrm{~s}$ ), were less inclined to write about droughts and famines (Liesegang 1993). Equally, colonial adjustments to food provision, such as the introduction of crops like winter wheat, may have reduced agricultural sensitivity to drier conditions (Hannaford 2018b), or colonial observers became more accustomed to the climate of the region and therefore found droughts less worthy of mention. That is to say, the apparent reduction in recording was in agricultural drought (failures of crops attributed to lack of water) or that recording of hydrometeorological drought (deficits in moisture and rainfall, particularly over single seasons) was deemed to be less important once a degree of (colonial) environmental knowledge had developed. However, if this was the 
predominant reason, then reports of drought would have been unlikely to increase again during the eighteenth century. Moreover, the colonial presence still depended on acquiring food from African and Swahili populations, where the crop mix remained largely consistent of sorghum, millet and rice (Hannaford 2018b). The limited recording of dry events in the early and late seventeenth century may therefore reflect the more mixed signals of palaeoclimate records over this period (Fig. 4).

Wetter periods in SRZE palaeoclimate records show mixed correspondence with the documentary chronology. For example, in the periods c. 1550-1600 and c. 1800-1830, several (but not all) palaeoclimate records indicate wetter conditions, yet a relatively high number of droughts were recorded (Fig. S1). However, most wet seasons across the chronology were also recorded during these periods. Conversely, the late eighteenth century shows increased signs of wetness in the palaeoclimate records, and although several droughts were reported in this period, they were all single-season length until the droughts of the 1790s. These mixed patterns may instead indicate that transitions in moisture availability were associated with higher inter-annual variability and greater recording of extremes of both signs (Fig. 4). Alternatively, the mixed signals could be associated with the complexities of SRZE moisture patterns, for example, due to Indian Ocean SSTs and shifts in the variability and mean state of the IOD and ENSO (Abram et al. 2020). The modulation of SRZE rainfall by multiple atmosphere-ocean drivers complicates interpretation of rainfall patterns and warrants further research over historical timescales.

Given the long timespan of the study, there is likely to be some relationship between the overall amount of documentary recording and reporting of climatic conditions. For example, there is probably some degree of randomness in the recording of individual rain-years based on the timing of richly descriptive accounts (e.g., shipwreck diaries). More fundamentally, there was a growth in the production of documentary evidence within Mozambique after its separation from the Viceroyalty of Goa after 1752, which could be expected to increase coverage of hydroclimate-related events. However, Table S1 suggests that this may simply have increased the number of references to the same event (thus providing higher confidence), or to individual dry rain-years, rather than severe, protracted and spatially extensive droughts. Fig. S1 reinforces the absence of a linear relationship over time, with a higher proportion of references to dry events in the late sixteenth century than the seventeenth or late eighteenth centuries, when documentary recording increased. Similarly, the early eighteenth century reduction in Portuguese documentation on Mozambique (Hannaford 2018a) does not correspond to a decrease in reported droughts.

The SRZW palaeoclimate records show a dry-wet-dry pattern across the LIA, with a predominance of wetter conditions across much of the later LIA from c. 1650 to 1800 . The documentary records, however, suggest considerable inter-annual variability and frequent drought across this period, with multi-season events clustered around the 1630s, 1650s, 1710 s-1720s, and 1780s-1790s. Comparison of documentary records with the lower resolution records from $\mathrm{KR}$ and $\mathrm{SP}$ is challenging. However, there is strong correspondence between the abovementioned drought clusters and the higher ${ }^{13} \mathrm{C}$ values in the DC records at c. 1650 , c. 1725 , and c. $1780-1800$, while lower $\delta^{13} \mathrm{C}$ values at c. $1575-1600$ and c. $1675-1700$ correspond to a reduction in reported droughts of any duration. The correspondence with drought and recurrent locust outbreaks at c. 1650 is particularly noteworthy given that $\delta^{13} \mathrm{C}$ values at this time in the DC2 reconstruction were the highest across the study period.

As in the SRZE, there is an increase in recording of rainfall extremes of both signs in the early nineteenth century, when the KR and SP records as well as the DC1 record show key 
hydroclimate transitions (Fig. 4). Documentary evidence from the turn of the nineteenth century elucidates the high inter-annual variability at this time, with Vasconcelos noting that 'we who live in this land are faced constantly with the choice between dying of hunger in the dry years or of sickness in the rainy ones, and in such a place what could prosper and who would want to live?' (Miller 1982, p. 54). The abruptness of transitions during the earlier part of the study period is obscured by the limited resolution of the records.

Increased reports of droughts over time in the Angolan documentary chronology suggest some role of growing production of documentary records as a whole. Yet this seems to relate more to the lesser degree of recording in the sixteenth century-when the later important Luanda was still a fledgling colonial settlement and Benguela had not yet been founded - than a gradual longer-term effect. This probably reduced recording of agricultural drought in the vicinity of Luanda during the earlier part of the study period, which thereafter become dominant in subsequent centuries when arimos (agricultural properties) became established along the Kwango and Bengo rivers (Thornton 2020).

\subsection{Drivers of rainfall variability: ENSO and summer rainfall}

Section 4.2 highlighted some of the key drivers modulating SRZE and SRZW hydroclimate variability during the LIA. Cooler SST anomalies in the SWIO coral records at c. 1680-1750 are associated with reduced moisture availability over the SRZE (Fig. 3). Cooler anomalies were also coeval with a transition to wetter moisture conditions in palaeoclimate records from the Winter Rainfall Zone of South Africa (Stager et al. 2012), which infer equatorward shifts in the westerly storm tracks (Woodborne et al. 2015). In the SRZW, a more southerly position of the ITCZ and reduced southeast Atlantic upwelling were associated with greater moisture availability during the LIA. Coherence between SRZW hydroclimate records and the eastern African lakes (Fig. 3) has also been linked to a westward shift in the position of the CAB (Nash et al. 2016a), resulting in drier conditions at northern SRZE sites such as LM (Fig. 3).

A further driver that has played an important role in modulating southern African summer rainfall in the twentieth century is ENSO, with the strongest SRZ moisture response in the rainyear following El Niño and La Niña events (Richard et al. 2000; Rouault and Richard 2005). However, longer duration studies of ENSO-rainfall relationships in the SRZE suggest that the nature of these links has been non-stationary(Woodborne et al. 2015, 2016), or that ENSO is not a simple determinant of rainfall anomalies (Nash et al. 2016b). The two documentary chronologies permit further analysis of links between ENSO and seasonal rainfall variability over long timescales.

Following Nash et al. (2016b), Table S3 displays documentary-derived moisture conditions in Mozambique and Angola across the study period during the austral summer immediately following each El Niño, La Niña, and neutral year as identified in a 500-year multi-proxy ENSO reconstruction (Gergis and Fowler 2009).

In the SRZE, 22 of the dry rain-years reported by historical observers followed El Niño years and 21 followed La Niña years, with a further 14 following neutral years. While this shows no overall dominant pattern, the temporal distribution of these associations is worthy of note. Ten of the 22 dry seasons that followed El Niño years occurred in just a 40 -year period between 1791 and 1830, whereas only three dry seasons followed La Niña years during the same period. By contrast, in the period up to 1700,11 dry seasons were preceded by La Niña years compared to six El Niño years. The split was more even in the intervening period of $\mathrm{c}$. 1700-1790, with seven dry events preceded by La Niña years and six by El Niño years. 
These temporal differences may lend support to the non-static correlation between southeast African summer rainfall and ENSO identified by Woodborne et al. (2015, 2016). Specifically, Woodborne et al. (2015) find that over most of the second millennium, drier conditions reconstructed from baobab trees at Pafuri were associated with La Niña conditions, while wet conditions were associated with El Niño conditions, suggesting a relatively recent inversion in this relationship to the modern climatological norm. Woodborne et al. (2016) add that the correlation of rainfall with ENSO is weak prior to c. 1650, but strong after c. 1750. Further evidence for such a shift is found in the timing of associations with wetter rain-years, despite their lower overall frequency in the documentary record. All of the five El Niño years that preceded wet rain-years in Mozambique occurred before the mid-eighteenth century, whereas five of the six La Niña years that preceded wet rain-years occurred after the mideighteenth century, demonstrating greater similarity with modern relationships in the later study period. It should be noted, however, that many rain-years following El Niño and La Niña years remain unclassified; therefore, these associations should be treated with caution.

In the SRZW, large-scale geographical coherence in late twentieth century ENSO-rainfall links was more variable than in the SRZE (Hoell et al. 2015; Section 2). Comparison of the Angola chronology with the 500-year ENSO reconstruction reveals that El Niño years preceded 24 dry rain-years (nine low confidence) and eight wet rain-years, La Niña years preceded 33 dry rain-years (five low confidence) and seven wet rain-years, and neutral events preceded 16 dry rain-years and two wet rain-years(Table S3). The temporal distribution of these links is broadly consistent across the study period. However, La Niña years correspond with a greater proportion of drier years during the eighteenth century, when most reports of extremes come from Luanda and Benguela. These relationships appear to correspond to the modern (negative) rainfall responses observed in coastal Angola following La Niña years (Hoell et al. 2015) in comparison to the more mixed rainfall responses in El Niño events.

\section{Conclusions}

This study has extended and revised existing documentary-derived chronologies of seasonal rainfall variability in southeast and west-central Africa and has compared these to a range of palaeoclimate proxy records covering the LIA. The documentary and palaeoclimate records indicate that the SRZE and SRZW were distinct regions of hydroclimate variability - both on seasonal and longer timescales - over much of the study period, supporting earlier findings (Nicholson 2014; Nash et al. 2016a). Within these two regions, the source types generally, but do not always, agree in their signals of hydroclimate variability. Both regions do, however, suggest agreement between hydroclimate transitions and increased documentary recording of (multi-)seasonal extremes of both signs. These patterns reflect both the nature of regional-local rainfall variability and the social context behind the recording of hydroclimate extremes in early colonial documentary sources. Moreover, while the documentary records used in this study perform particularly well at capturing extremes at the inter-annual to decadal scale, they are less effective at capturing mean state rainfall variability. A further finding is that the Mozambique documentary chronology suggests that long-term hydroclimate links with ENSO are complex and possibly non-stationary, demonstrating the need for further research into the nature of these relationships over long time periods.

Overall, despite the limitations of documentary and palaeoclimate sources in southern Africa prior to the early nineteenth century, this paper demonstrates that both source types 
are important to, and complementary in, improving our understanding of African climates in the centuries prior to instrumental recording. More hydroclimate-related events may be added to the documentary chronologies through additional archival work; however, it is likely that researchers have reached the point of diminishing returns in both regions in the pre-1830 period, particularly for multi-seasonal droughts, which seem to be well-captured even in periods of reduced documentary recording. In-depth research revisiting and expanding other climatic chronologies developed from early colonial records could help constrain the temporal and geographical patterns in LIA rainfall variability across the African continent, where palaeoclimate records are increasing but remain sparse. Any such research, however, must be carefully grounded in the production context of the documentary records if it is to disentangle the environmental and social drivers that underlie the chronologies.

Supplementary Information The online version contains supplementary material available at https://doi.org/ 10.1007/s10584-021-03217-7.

Code availability Not applicable.

Author contribution Conceptualisation: Matthew Hannaford, Kristen Beck. Data collection: Matthew Hannaford; Methodology: Matthew Hannaford, Kristen Beck. Analysis: Matthew Hannaford, Kristen Beck. Writing: Matthew Hannaford, Kristen Beck.

Data availability The documentary chronology datasets generated and analysed during this study are included in supplementary information file (Section S3). The palaeoclimate data analysed is available in the NOAA Paleoclimatology repository, https://www.ncdc.noaa.gov/paleo-search/

\section{Declarations}

Ethics approval Not applicable.

Consent to participate Not applicable.

Consent for publication Not applicable.

Conflict of interest The authors declare no competing interests.

Open Access This article is licensed under a Creative Commons Attribution 4.0 International License, which permits use, sharing, adaptation, distribution and reproduction in any medium or format, as long as you give appropriate credit to the original author(s) and the source, provide a link to the Creative Commons licence, and indicate if changes were made. The images or other third party material in this article are included in the article's Creative Commons licence, unless indicated otherwise in a credit line to the material. If material is not included in the article's Creative Commons licence and your intended use is not permitted by statutory regulation or exceeds the permitted use, you will need to obtain permission directly from the copyright holder. To view a copy of this licence, visit http://creativecommons.org/licenses/by/4.0/.

\section{References}

Abram NJ, Hargreaves JA, Wright NM, Thirumalai K, Ummenhofer CC, England MH (2020) Palaeoclimate perspectives on the Indian Ocean Dipole. Quat Sci Rev 237:106302. https://doi.org/10.1016/j.quascirev. 2020.106302 
Allan R, Endfield G, Damodaran V, Adamson G, Hannaford M, Carroll F, Macdonald N, Groom N, Jones J, Williamson F, Hendy E, Holper P, Arroyo-Mora JP, Hughes L, Bickers R, Bliuc A-M(2016) Toward integrated historical climate research: the example of Atmospheric Circulation Reconstructions over the Earth. WIREs Clim Change 7:164-174. https://doi.org/10.1002/wcc.379

Axelson E (1960) Portuguese in South-East Africa, 1600-1700. Witwatersrand University Press, Johannesburg

Bahana JW, Ngazero AK (1999) A locust plague in the making: upsurges of the red locust, Nomadacris septemfasciata (Serville) in Buzi-Gorongosa outbreak area, Mozambique in 1996. International Journal of Tropical Insect Science 19:291-300. https://doi.org/10.1017/S1742758400018919

Beach DN (1987) Documents and African society on the Zimbabwean plateau before 1890. Paideuma 33:129-145

Braun K, Nehme C, Pickering R, Rogerson M, Scroxton N (2019) A window into Africa's past hydroclimates: the SISAL_v1 database contribution. Quaternary 2. https://doi.org/10.3390/quat2010004

Chase BM, Meadows M, Scott L, Thomas D, Marais E, Sealy J, Reimer P (2009) A record of rapid Holocene climate change preserved in hyrax middens from southwestern Africa. Geology 37:703-706. https://doi.org/ 10.1130/G30053A.1

Chirikure S, Nyamushosho RT, Chimhundu H, Dandara C, Pamburai HH, Manyanga M (2017) Concept and knowledge revision in the post-colony: mukwerera, the practice of asking for rain amongst the Shona of southern Africa. In: Manyanga M, Chirikure S (eds) Archives, objectives, places and landscapes: multidisciplinary approaches to decolonised Zimbabwean pasts. Langa, Bamenda, pp 15-54

Crétat J, Pohl B, Dieppois B, Berthou S, Pergaud J (2019) The Angola low: relationship with southern African rainfall and ENSO. Clim Dyn 52:1783-1803. https://doi.org/10.1007/s00382-018-4222-3

Dias JR (1981) Famine and disease in the history of Angola c. 1830-1930. J Afr Hist 22:349-378. https://doi. org/10.1017/S0021853700019575

Ekblom A, Stabell B (2008) Paleohydrology of Lake Nhaucati (southern Mozambique), 400 AD to present. J Paleolimnol 40:1127-1141. https://doi.org/10.1007/s10933-008-9218-2

Ekblom A, Gillson L, Risberg J, Holmgren K, Chidoub Z (2012) Rainfall variability and vegetation dynamics of the lower Limpopo Valley, southern Africa, 500AD to present. Palaeogeogr Palaeoclimatol Palaeoecol 363364:69-78. https://doi.org/10.1016/j.palaeo.2012.08.015

Farmer EC, deMenocal PB, Marchitto TM (2005) Holocene and deglacial ocean temperature variability in the Benguela upwelling region: implications for low-latitude atmospheric circulation. Paleoceanography 20. https://doi.org/10.1029/2004PA001049

Fohlmeister J, Voarintsoa NRG, Lechleitner FA, Boyd M, Brandtstätter S, Jacobson MJ, Oster JL (2020) Main controls on the stable carbon isotope composition of speleothems. Geochim Cosmochim Acta 279:67-87. https://doi.org/10.1016/j.gca.2020.03.042

Gergis JL, Fowler AM (2009) A history of ENSO events since A.D. 1525: implications for future climate change. Clim Chang 92:343-387. https://doi.org/10.1007/s10584-008-9476-Z

Gillett NP, Kell TD, Jones PD (2006) Regional climate impacts of the southern annular mode. Geophys Res Lett 33:L23704. https://doi.org/10.1029/2006GL027721

Grab S, Zumthurm T (2018) The land and its climate knows no transition, no middle ground, everywhere too much or too little: a documentary-based climate chronology for Central Namibia, 1845-1900. Int J Climatol 38:e643-e659. https://doi.org/10.1002/joc.5397

Hall M (1976) Dendroclimatology, rainfall and human adaptation in the later Iron Age of Natal and Zululand. Annals of the Natal Museum 22:693-703

Hannaford MJ (2018a)Pre-colonial South-East Africa: sources and prospects for research in economic and social history. J South Afr Stud 44:771-792. https://doi.org/10.1080/03057070.2018.1508864

Hannaford MJ (2018b)Long-term drivers of vulnerability and resilience to drought in the Zambezi-Save area of southern Africa, 1505-1830. Glob Planet Chang 166:94-106. https://doi.org/10.1016/j.gloplacha.2018.05. 001

Hannaford M (2020) Climate change and society in Southern African history. Oxford Research Encyclopedia of African History. https://doi.org/10.1093/acrefore/9780190277734.013.294

Hannaford MJ, Nash DJ (2016) Climate, history, society over the last millennium in southeast Africa. WIREs Clim Change 7:370-392. https://doi.org/10.1002/wcc.389

Hannaford MJ, Jones JM, Bigg GR (2015)Early-nineteenth-century southern African precipitation reconstructions from ships' logbooks. The Holocene 25:379-390. https://doi.org/10.1177/0959683614557573

Hoell A, Funk C, Magadzire T, Zinke J, Husak G (2015) El Niño-Southern Oscillation diversity and southern Africa teleconnections during austral summer. Clim Dyn 45:1583-1599. https://doi.org/10.1007/s00382-014-2414-Z

Holmgren K, Karlén W, Lauritzen SE, Lee-Thorp JA, Partridge TC, Piketh S, Repinski P, Stevenson C, Svanered O, Tyson PD (1999) A 3000-year high-resolution stalagmite-based record of palaeoclimate for northeastern South Africa. The Holocene 9:295-309. https://doi.org/10.1191/095968399672625464 
Holmgren K, Lee-Thorp JA, Cooper G.R, Lundblad K, Partridge TC, Scott L, Sithaldeen R, Talma AS, Tyson PD (2003) Persistent millennial-scale climatic variability over the past 25,000 years in southern Africa. Quat Sci Rev 22:2311-2326. https://doi.org/10.1016/S0277-3791(03)00204-X

Johnson TC, Barry SL, Chan Y, Wilkinson P (2001) Decadal record of climate variability spanning the past $700 \mathrm{yr}$ in the southern tropics of East Africa. Geology 29:83-86. https://doi.org/10.1130/0091-7613(2001) $029<0083$ :DROCVS>2.0.CO;2

Jones A (1987) The dark continent: a preliminary study of the geographical coverage in European sources, 14001880. Paideuma 33:19-26

Jury MR, Engert S (1999) Teleconnections modulating inter-annual climate variability over northern Namibia. Int J Climatol 19:1459-1475. https://doi.org/10.1002/(SICI)1097-0088(19991115)19:13<1459::AIDJOC397>3.0.CO;2-A

Kelso C, Vogel C (2007) The climate of Namaqualand in the nineteenth century. Clim Chang 83:357-380. https://doi.org/10.1007/s10584-007-9264-1

Kiss A (2017) Droughts and low water levels in late medieval Hungary II: 1361, 1439, 1443-4, 1455, 1473, 1480, 1482(?), 1502-3, 1506: documentary versus tree-ring(OWDA) evidence. Journal of Environmental Geography 10. https://doi.org/10.1515/jengeo-2017-0012

Lachniet MS (2009) Climatic and environmental controls on speleothem oxygen-isotope values. Quat Sci Rev 28:412-432. https://doi.org/10.1016/j.quascirev.2008.10.021

Lechleitner FA, Breitenbach SFM, Rehfeld K, Ridley HE, Asmerom Y, Prufer KM, Marwan, N, Goswami B, Kennett DJ, Aquino VV, Polyak V, Haug G.H, Eglinton TI, Baldini JUL (2017) Tropical rainfall over the last two millennia: evidence for a low-latitude hydrologic seesaw. Sci Rep 7:45809. https://doi.org/10.1038/srep45809

Liesegang GJ (1993) Technology, space, climate, and biology: the incidence and impact of drought, famines, pests, epidemics, and wars in the history of Mozambique, c. 1515-1990. Unpublished manuscript, Maputo

Meteorology Department/Florida State University (1980) Nicholson's Africa precipitation, monthly 1901-1984. Research Data Archive at the National Center for Atmospheric Research, Computational and Information Systems Laboratory https://rda.ucar.edu/datasets/ds571.0/. Accessed 23 December 2020

Miller JC (1982) The significance of drought, disease and famine in the agriculturally marginal zones of westcentral Africa. J Afr Hist 23:17-61. https://doi.org/10.1017/S0021853700020235

Nash DJ, Endfield GH (2002) A 19th century climate chronology for the Kalahari region of central southern Africa derived from missionary correspondence. Int J Climatol 22:821-841. https://doi.org/10.1002/joc.753

Nash DJ, Hannaford MJ (2020) Historical climatology in Africa: a state of the art. Past Global Changes Magazine 28:42-43. https://doi.org/10.22498/pages.28.2.42

Nash DJ, De Cort G, Chase BM, Verschuren D, Nicholson SE, Shanahan TM, Asrat A, Lézine AM, Grab SW (2016a) African hydroclimatic variability during the last 2000 years. Quat Sci Rev 154:1-22. https://doi.org/ 10.1016/j.quascirev.2016.10.012

Nash DJ, Pribyl K, Klein J, Neukom R, Endfield GH, Adamson GCD, Kniveton DR (2016b) Seasonal rainfall variability in southeast Africa during the nineteenth century reconstructed from documentary sources. Clim Chang 134:605-619. https://doi.org/10.1007/s10584-015-1550-8

Nash DJ, Pribyl K, Endfield GH, Klein J, Adamson GCD (2018) Rainfall variability over Malawi during the late 19th century. Int J Climatol 38:e629-e642. https://doi.org/10.1002/joc.5396

Nash DJ, Klein J, Endfield GH, Pribyl K, Adamson GCD, Grab SW (2019) Narratives of nineteenth century drought in southern Africa in different historical source types. Clim Chang 152:467-485. https://doi.org/10. 1007/s10584-018-2352-6

Neukom R, Gergis J (2012) Southern hemisphere high-resolution palaeoclimate records of the last 2000 years. The Holocene 22:501-524. https://doi.org/10.1177/0959683611427335

Neukom R, Nash DJ, Endfield GH, Grab SW, Grove CA, Kelso C, Vogel CH, Zinke J (2013)Multi-proxy summer and winter precipitation reconstruction for southern Africa over the last 200 years. Clim Dyn 42: 2713-2726. https://doi.org/10.1007/s00382-013-1886-6

Newitt MDD (1988) Drought in Mozambique 1823-1831. J South Afr Stud 15:15-35. https://oi.org/10.1080/ 03057078808708189

Nicholson SE (1979) The methodology of historical climate reconstruction and its application to Africa. J Afr Hist 20:31-49. https://doi.org/10.1017/S0021853700016704

Nicholson SE (1996) Environmental change within the historical period. In: Goudie AS, Adams WM, Orme A (eds) The physical geography of Africa. Oxford University Press, Oxford, pp 60-75

Nicholson SE (2000) The nature of rainfall variability over Africa on time scales of decades to millenia. Glob Planet Chang 26:137-158. https://doi.org/10.1016/S0921-8181(00)00040-0

Nicholson SE (2014) Spatial teleconnections in African rainfall: a comparison of 19th and 20th century patterns. The Holocene 24:1840-1848. https://doi.org/10.1177/0959683614551230

Nicholson SE (2018) A multi-century history of drought and wetter conditions in Africa. In: White S, Pfister C, Mauelshagen F (eds) The Palgrave handbook of climate history. Palgrave Macmillan, London, pp 225-236 
Pikirayi I (2003) Environmental data and historical process. Historical climatic reconstruction and the Mutapa State 1450-1862. Social History and African Environments. James Currey: Oxford, pp 60-71

Richard Y, Trzaska S, Roucou P, Rouault M (2000) Modification of the southern African rainfall variability/ ENSO relationship since the late 1960s. Clim Dyn 16:883-895. https://doi.org/10.1007/s003820000086

Rouault M, Richard Y (2005) Intensity and spatial extent of droughts in southern Africa. Geophys Res Lett 32: L15702. https://doi.org/10.1029/2005GL022436

Rouault M, Florenchie P, Fauchereau N, Reason CJC (2003) South east tropical Atlantic warm events and southern African rainfall. Geophys Res Lett 30. https://doi.org/10.1029/2002GL014840

Scott L (1996) Palynology of hyrax middens: 2000 years of palaeoenvironmental history in Namibia. Quat Int 33:73-79. https://doi.org/10.1016/1040-6182(95)00093-3

Scroxton N, Burns SJ, Mcgee D, Hardt B, Godfrey LR, Ranivoharimanana L, Faina P (2017) Hemispherically in-phase precipitation variability over the last 1700 years in a Madagascar speleothem record. Quat Sci Rev 164:25-36. https://doi.org/10.1016/j.quascirev.2017.03.017

Sletten HR, Railsback LB, Liang F, Brook GA, Marais E, Hardt BF, Cheng H, Edwards RL (2013) A petrographic and geochemical record of climate change over the last 4600years from a northern Namibia stalagmite, with evidence of abruptly wetter climate at the beginning of southern Africa's Iron Age. Palaeogeogr Palaeoclimatol Palaeoecol 376:149-162. https://doi.org/10.1016/j.palaeo.2013.02.030

Stager JC, Mayewski PA, White J, Chase BM, Neumann FH, Meadows ME, King CD, Dixon DA (2012) Precipitation variability in the winter rainfall zone of South Africa during the last $1400 \mathrm{yr}$ linked to the austral westerlies. Clim Past 8:877-887. https://doi.org/10.5194/cp-8-877-2012

Stager JC, Ryves DB, King C, Madson J, Hazzard M, Neumann FH, Maud R (2013) Late Holocene precipitation variability in the summer rainfall region of South Africa. Quat Sci Rev 67:105-120. https://doi.org/10.1016/ j.quascirev.2013.01.022

Steedman A (1990) Locust handbook. Chatham, Natural Resources Institute

Sundqvist HS, Holmgren K, Fohlmeister J, Zhang Q, Matthews MB, Spötl C, Körnich H (2013) Evidence of a large cooling between 1690 and $1740 \mathrm{AD}$ in southern Africa. Sci Rep 3:1767. https://oi.org/10.1038/srep01767

Thornton JK (2020) A history of West Central Africa to 1850, new approaches to African history. Cambridge University Press, Cambridge

Tierney JE, Smerdon JE, Anchukaitis KJ, Seager R (2013) Multidecadal variability in East African hydroclimate controlled by the Indian Ocean. Nature 493:389-392. https://doi.org/10.1038/nature11785

Trabucco A, Zomer R (2018) Global Aridity and PET Database. Global Aridity Index and Global Potential Evapo-transpiration Geospatial Database. CGIAR-CSI GeoPortal. https://cgiarcsi.community/data/globalaridity-and-pet-database/. Accessed 1 April 2021)

van Bavel BJP, Curtis DR, Hannaford MJ, Moatsos M, Roosen J, Soens T (2019) Climate and society in longterm perspective: opportunities and pitfalls in the use of historical datasets. WIREs Clim Change 10:e611. https://doi.org/10.1002/wcc.611

Voarintsoa NRG, Brook GA, Liang F, Marais E, Hardt B, Cheng H, Edwards RL, Railsback LB (2017) Stalagmite multi-proxy evidence of wet and dry intervals in northeastern Namibia: linkage to latitudinal shifts of the Inter-Tropical Convergence Zone and changing solar activity from AD 1400 to 1950 . The Holocene 27:384-396. https://doi.org/10.1177/0959683616660170

Vogel CH (1989) A documentary-derived climatic chronology for South Africa, 1820-1900. Clim Chang 14: 291-307. https://doi.org/10.1007/BF00134967

White S (2019) A comparison of drought information in early North American colonial documentary records and a highresolutiontree-ring-based reconstruction. Clim Past 15:1809-1824. https://oi.org/10.5194/cp-15-1809-2019

Williams CJR, Kniveton DR, Layberry R (2007) Climatic and oceanic associations with daily rainfall extremes over southern Africa. Int J Climatol 27:93-108. https://doi.org/10.1002/joc.1376

Woodborne S, Hall G, Robertson I, Patrut A, Rouault M, Loader NJ, Hofmeyr M (2015) A 1000-year carbon isotope rainfall proxy record from south African baobab trees (Adansonia digitata L.). PLoS One 10: e0124202. https://doi.org/10.1371/journal.pone.0124202

Woodborne S, Gandiwa P, Hall G, Patrut A, Finch J (2016) A regional stable carbon isotope dendro-climatology from the south African summer rainfall area. PLoS One 11:e0159361. https://doi.org/10.1371/journal.pone. 0159361

Zinke J, Loveday BR, Reason CJC, Dullo W-C, Kroon D (2014) Madagascar corals track sea surface temperature variability in the Agulhas current core region over the past 334 years. Sci Rep 4:4393. https://doi.org/10.1038/srep04393

Publisher's note Springer Nature remains neutral with regard to jurisdictional claims in published maps and institutional affiliations. 